\title{
Combined effects of the proteasome inhibitor bortezomib and Hsp70 inhibitors on the B16F10 melanoma cell line
}

\author{
AZMI YERLIKAYA ${ }^{1}$, EMRAH OKUR $^{1}$, SEMIH ŞEKER $^{1}$ and NURAY ERIN ${ }^{2}$ \\ ${ }^{1}$ Department of Biology, Art and Science Faculty, Dumlupinar University, Kütahya; \\ ${ }^{2}$ Department of Internal Medicine, Akdeniz University, Antalya, Turkey
}

Received August 26, 2009; Accepted January 8, 2010

DOI: $10.3892 / \mathrm{mmr} \_00000262$

\begin{abstract}
Studies have shown that the 26S proteasome is involved in cell cycle control, transcription, DNA repair, immune response and protein synthesis. In the present study, we investigated the antiproliferative effects of the proteasome inhibitor bortezomib and heat shock protein (Hsp)70 inhibitors on the $\mathrm{B} 16 \mathrm{~F} 10$ melanoma cell line. The $\mathrm{IC}_{50}$ value of bortezomib was found to be $2.46 \mathrm{nM}$, while that of the Hsp70 inhibitor quercetin was $45 \mu \mathrm{M}$ in the $\mathrm{B} 16 \mathrm{~F} 10$ cells. This indicates that bortezomib is more effective than quercetin in inhibiting cell growth. In response to treatment with $10 \mathrm{nM}$ bortezomib for $24 \mathrm{~h}$, cells underwent rounding, shrinkage and detachment. Unexpectedly, such morphological changes were not observed in cells treated with $20 \mu \mathrm{M}$ quercetin alone, nor in cells treated with bortezomib + quercetin, indicating that quercetin inhibited the cytotoxic effects of bortezomib. Quantitation of cell viability also indicated that quercetin interfered with the cytotoxic effects of bortezomib. However, the combination of quercetin with another proteasome inhibitor, MG132, caused significant cell death as compared to single-agent treatment. A DNA ladder assay also confirmed the inhibitory effect of quercetin on the apoptosis-inducing effect of bortezomib. However, quercetin did not prevent the induction of apoptosis by MG132; on the contrary, it potentiated the apoptosis-inducing effect of MG132. These results suggest that the combination of quercetin with clinically beneficial proteasome inhibitors (except bortezomib) may have increased efficacy in the treatment of cancer. We also tested the combination of two other Hsp70 inhibitors, KNK-437 and schisandrin-B, in combination with bortezomib. Neither of these combinations was more effective than single-agent treatment.
\end{abstract}

Correspondence to: Dr Azmi Yerlikaya, Department of Biology, Art and Science Faculty, Dumlupinar University, Kütahya 43100, Turkey

E-mail: ayerlikaya@dumlupinar.edu.tr

Abbreviations: $\mathrm{IC}_{50}$, half maximal inhibitory concentration; Hsp, heat shock protein; MTT, (3-(4,5-dimethythiazol-2-yl)-2,5-diphenyltetrazolium bromide; eIF2, eukaryotic translational initiation factor 2

Key words: proteasome, heat shock protein 70, bortezomib, quercetin, KNK-437, schisandrin-B

\section{Introduction}

Cellular homeostasis is maintained by the continual synthesis and degradation of proteins in a highly regulated manner $(1,2)$. The ubiquitin-proteasome pathway is involved in cellular homeostasis by eliminating abnormal, mutant and misfolded proteins. The $26 \mathrm{~S}$ proteasome is a large ATP-dependent protease and is found in both the cytosol and the nucleus. It is a multi-catalytic and multi-subunit protease formed by the assembly of approximately 64 subunits. The proteasome is composed of one $20 \mathrm{~S}$ core complex and two $19 \mathrm{~S}$ regulatory complexes, which are attached to both ends of the 20S core complex. The eukaryotic 20S complex has a cylindrical structure and is made up of four rings. The two inner rings are formed from seven distinct $\beta$-subunits; the two outer rings are formed from seven distinct $\alpha$-subunits. Substrate proteins are commonly degraded to peptides with an average length of 7-9 within the catalytic chamber of the $20 \mathrm{~S}$ core complex, which harbors at least three different proteolytic activities (i.e., trypsin-like, chymotrypsin-like and peptidylglutamyl-peptide hydrolyzing activities) (3-7). The 19S regulatory complex is composed of a base and a lid and is believed to carry out several critical functions during the degradation of target proteins. For example, the six ATPases found in the base complex are thought to be involved in unfolding and threading substrate proteins into the catalytic chamber of the $20 \mathrm{~S}$ complex, while the eight subunits found in the lid complex are mostly involved in the recognition of ubiquitinated proteins and the subsequent de-ubiquitination process $(8,9)$. Studies have shown that a number of key regulatory proteins are degraded by the $26 \mathrm{~S}$ proteasome; among these are cyclin-dependent kinase inhibitors, M-, S-, G1-phase cyclins, p53, c-fos, ornithine decarboxylase and S-adenosylmethionine decarboxylase $(4,10-13)$. The substrate proteins are commonly targeted to the $26 \mathrm{~S}$ by a polyubiquitin chain. The conjugation of ubiquitin (a 76-amino acid protein) usually requires three enzymatic steps (14-18). Numerous studies have revealed that the ubiquitinproteasome system is responsible for the degradation of more than $80 \%$ of intracellular proteins (19). Given a broad array of substrates, the $26 \mathrm{~S}$ proteasome was shown to be involved in cell cycle control, cell differentiation, transcription, DNA repair, immune response, retroviral budding and translation $(3,4,20-23)$. 
We previously showed that the level of most intracellular amino acids was increased as a result of a significant decrease in protein synthesis activity in response to the inhibition of the $26 \mathrm{~S}$ proteasome in a short period of time. Moreover, we found that the decrease in protein synthesis activity was due to a significant increase in eukaryotic translational initiation factor $2 \alpha$ (eIF $2 \alpha$ ) phosphorylation (21). It was also previously found that the inhibition of the proteasome by MG132 or lactacystin induced the expression of heat shock protein (Hsp) 25 and Hsp70, which are molecular chaperones involved in the folding of nascent proteins and the regulation of proteinprotein interactions $(24,25)$. The induction of Hsp70 or Hsp27 protein by a mild heat shock treatment or stable transfection was found to increase the resistance of U937 and Wehi-s cells to apoptotic cell death (26). Furthermore, it was shown that the depletion of intracellular Hsp70 by two different strategies (antisense technology or the bioflavonoid drug quercetin) led to apoptosis in the absence of stress (25). Therefore, to enhance the apoptotic effects of proteasome inhibition, we examined the effects of the combination of the proteasome inhibitor bortezomib and several Hsp70 inhibitors in B16F10 melanoma cells.

\section{Materials and methods}

Materials. RPMI-1640 cell culture media, fetal bovine serum (FBS), trypsin and penicillin/streptomycin were obtained from Sigma-Aldrich Inc. MTT (3-(4,5-dimethylthiazol-2yl)-2,5-diphenyltetrazolium bromide) was kindly provided by Dr Diane McCloskey (Penn State University College of Medicine, Hershey, PA, USA). The Apoptotic-DNA Ladder kit was obtained from Roche Applied Science. All other reagents were purchased from Sigma-Aldrich Inc. unless otherwise mentioned.

Cell culture maintenance. B16F10 cells were maintained in RPMI-1640 (plus $4.5 \mathrm{~g} / 1$ glucose, $10 \mathrm{mM}$ HEPES, $1 \mathrm{mM}$ sodium pyruvate, $0.15 \%$ sodium bicarbonate, $100 \mu \mathrm{g} / \mathrm{ml}$ streptomycin and $100 \mathrm{U} / \mathrm{ml}$ penicillin) supplemented with $10 \%$ FBS. Cells were incubated in a humidified atmosphere at $37^{\circ} \mathrm{C}$ in $5 \% \mathrm{CO}_{2}$. Stock cultures were maintained in $25-\mathrm{cm}^{2}$ Corning flasks, and experimental cultures were grown in 35x10-mm Corning plates. The cells were subcultured upon reaching $70-80 \%$ confluence.

MTT-based cytotoxicity assay. Equal numbers of cells were seeded in each plate $(35 \times 10 \mathrm{~mm})$. Cells in the exponential phase of growth were treated with various doses of bortezomib $(0.001,0.01,0.05,0.1$ or $1 \mu \mathrm{M})$ or quercetin $(0.1$, $1,10,50,100$ and $200 \mu \mathrm{M})$ for $24 \mathrm{~h}$ for $\mathrm{IC}_{50}$ determination. After treatment, the cells were incubated with RPMI-1640 medium containing $0.5 \% \mathrm{FBS}+0.5 \mathrm{mg} / \mathrm{ml} \mathrm{MTT}$ at $37^{\circ} \mathrm{C}$ in $5 \% \mathrm{CO}_{2}$ to determine the number of surviving cells. Control cells were incubated with the MTT-containing medium for $4 \mathrm{~h}$ in the absence of bortezomib or quercetin. After removal of the medium and MTT, cells in each plate were incubated with $3 \%$ SDS $(200 \mu \mathrm{l})+1 \mathrm{ml} 40 \mathrm{mM} \mathrm{HCl}$ /isopropanol for $15 \mathrm{~min}$ at room temperature with intermittent shaking to dissolve the MTT-formazan crystals. The homogenate in each plate was pipetted well to dissolve the MTT-formazan crystals completely and centrifuged at 12,000 rpm for $5 \mathrm{~min}$. Absorbance at $570 \mathrm{~nm}$ was recorded with a Bio-Rad Smartspec Plus spectrophotometer. The $\mathrm{IC}_{50}$ values were then obtained by fitting the data with GraphPad Prism 3.03 software to a sigmoidal dose-response curve (for quercetin) or to a sigmoidal dose-response (variable slope) curve (for bortezomib).

Determination of DNA fragmentation. Cells $(100,000)$ were seeded in 35x10-mm sterile Petri dishes. In the logarithmic phase of growth, cells were treated with $20 \mu \mathrm{M}$ quercetin, $10 \mathrm{nM}$ bortezomib or $0.5 \mu \mathrm{M}$ MG132 for $48 \mathrm{~h}$. Cells were also treated with drug combinations $(20 \mu \mathrm{M}$ quercetin + $10 \mathrm{nM}$ bortezomib or $20 \mu \mathrm{M}$ quercetin $+0.5 \mu \mathrm{M}$ MG132) for $48 \mathrm{~h}$. After treatment, both detached and attached cells were combined and resuspended in $200 \mu \mathrm{l}$ PBS. DNA was then isolated using the Roche Apoptotic DNA Ladder kit as described in the manufacturer's protocol. Equal amounts of DNA $(0.5 \mu \mathrm{g})$ from each sample were separated by $1.5 \%$ agarose gel electrophoresis at $80 \mathrm{~V}$ for $2 \mathrm{~h}$. DNA was finally visualized by ethidium bromide staining under UV light.

Statistical analysis. Data were analyzed and graphed using GraphPad Prism 3.03 software. Where appropriate, one-way ANOVA and the Bonferroni's multiple comparison post-test were used to evaluate statistical significance. A p-value $<0.05$ was considered significant.

\section{Results}

Initially, we examined the antiproliferative and cytotoxic effects of the proteasome inhibitor bortezomib in B16F10 cells. Cells were treated with various concentrations of bortezomib (ranging from $1 \mathrm{nM}$ to $1 \mu \mathrm{M}$ ) for $24 \mathrm{~h}$, then viability was determined by an MTT-based cytotoxicity assay. Bortezomib caused a dose-dependent reduction in cell viability with an $\mathrm{IC}_{50}$ of $2.46 \mathrm{nM}$, indicating that $\mathrm{B} 16 \mathrm{~F} 10$ cells were highly sensitive to the proteasome inhibitor bortezomib. The B16F10 cells were also treated with increasing doses of the bioflavonoid quercetin (ranging from $100 \mathrm{nM}$ to $200 \mu \mathrm{M}$ ) in a logarithmic growth phase for a period of $24 \mathrm{~h}$. The antiproliferative effects of quercetin were similarly determined by the MTT-based assay. The Hsp70 inhibitor quercetin also reduced cell number in a concentration-dependent manner, with an $\mathrm{IC}_{50}$ of $45 \mu \mathrm{M}$. This result indicated that the $\mathrm{B} 16 \mathrm{~F} 10$ cells were also sensitive to quercetin, though bortezomib was a more potent inducer of cell death than quercetin.

In light of these findings, we treated the cells with low concentrations of bortezomib and quercetin in order to determine whether or not the two inhibitors act synergistically. As shown in Fig. 1, in response to treatment with $10 \mathrm{nM}$ bortezomib for $24 \mathrm{~h}$, cells underwent rounding, shrinkage and detachment, characteristic features of apoptotic cell death. However, such morphological changes were not observed in cells treated with $20 \mu \mathrm{M}$ quercetin alone for $24 \mathrm{~h}$. Unexpectedly, in the combination treatment, it was observed that quercetin prevented the morphological changes induced by bortezomib (Fig. 1). This indicated that the addition of quercetin did not significantly enhance the cytotoxic effects of bortezomib. On the contrary, the addition prevented the bortezomib-induced morphological changes commonly observed in apoptotic cells. 
Control

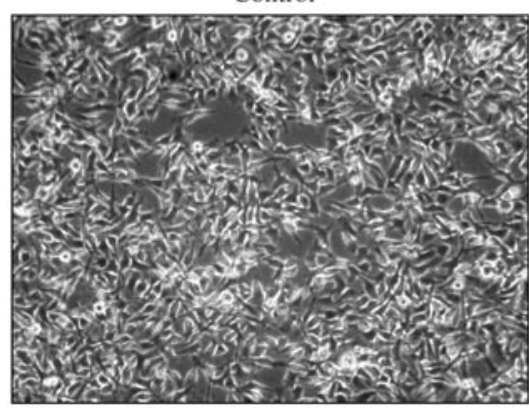

Bortezomib

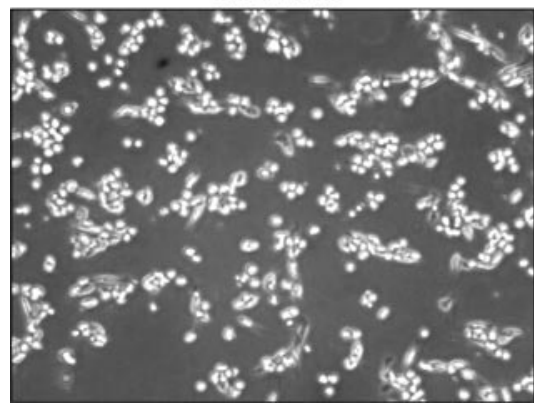

Quercetin

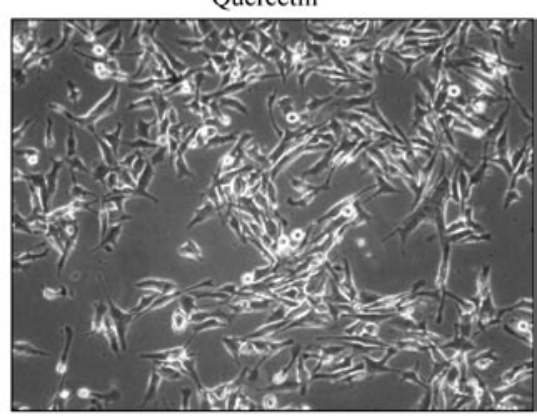

Bortezomib + Quercetin

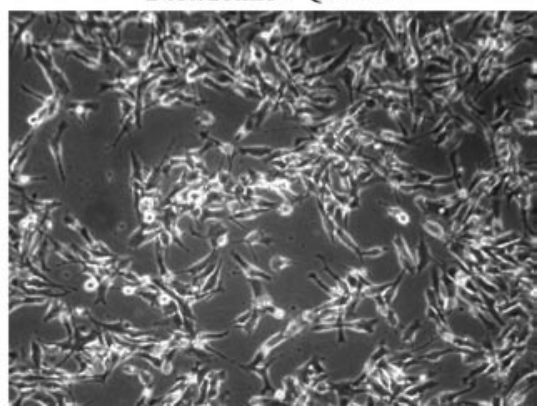

Figure 1. Analysis of cell morphology after treatment with a combination of quercetin and bortezomib. Cells were plated equally in sterile $35 \mathrm{x} 10$-mm Petri dishes and treated with DMSO (control), bortezomib $(10 \mathrm{nM})$, quercetin $(20 \mu \mathrm{M})$, or bortezomib $(10 \mathrm{nM})+\mathrm{quercetin}(20 \mu \mathrm{M})$ for $24 \mathrm{~h}$. After treatment, cell morphology was visualized with an inverted microscope (magnification x100). The results are representative of three separate experiments.

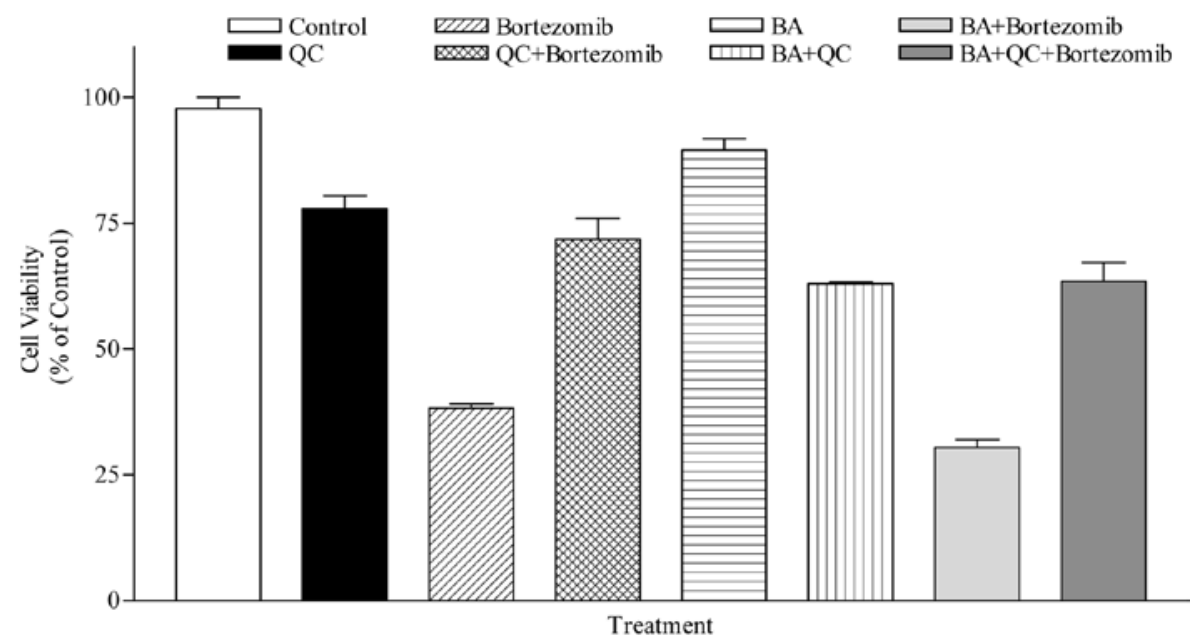

Figure 2. Effect of the combination of boric acid, quercetin and bortezomib on B16F10 cell viability. Cells were plated equally in sterile 35x10-mm Petri dishes and treated for $24 \mathrm{~h}$ with DMSO (control), bortezomib (10 nM), quercetin $(\mathrm{QC})(20 \mu \mathrm{M})$, or $1 \mathrm{mM}$ boric acid (BA) alone, or with combinations of QC (20 $\mu \mathrm{M})$ + bortezomib $(10 \mathrm{nM}), \mathrm{BA}(1 \mathrm{mM})+$ bortezomib $(10 \mathrm{nM})$, BA $(1 \mathrm{mM})+\mathrm{QC}(20 \mu \mathrm{M})$, or BA $(1 \mathrm{mM})+\mathrm{QC}(20 \mu \mathrm{M})+$ bortezomib (10 nM). Cell viability was then determined by an MTT-based assay as described in Materials and methods. Results are presented as the mean \pm SEM $(n=3)$.

Recently, Liu et al demonstrated a chemical reaction between quercetin and bortezomib, and found that the inhibitory effect of quercetin on bortezomib-induced apoptosis were reversed by boric acid pre-treatment in DoHH2 and CLL cells (27). We tested the effect of the combination of quercetin and bortezomib in the presence of $1 \mathrm{mM}$ boric acid using an MTT assay. As shown in Fig. 2, in the control group treated with $0.1 \%$ DMSO, $97.7 \pm 2.2 \%$ of cells were viable. In the $10 \mathrm{nM}$ bortezomib-treated group, cell viability was estimated to be $38.2 \pm 0.9 \%$. In contrast, in the $20 \mu \mathrm{M}$ quercetin-treated group, $77.8 \pm 2.6 \%$ of cells remained viable after treatment, while in the bortezomib + quercetin group, $71.8 \pm 4.22 \%$ of cells remained viable (Fig. 2 ). In the boric acid + quercetin + borteozmib treatment group, cell viability was estimated to be $63.4 \pm 3.7 \%$, indicating that although boric acid supplementation increased cell death as compared to the bortezomib + quercetin group, it did not completely prevent the interaction between the two inhibitors at a concentration of $1 \mathrm{mM}$. Collectively, these findings suggest that i) quercetin prevents the cytotoxic effects of bortezomib in B16F10 cells, and ii) boric acid supplementation at a concentration of $1 \mathrm{mM}$ does not prevent the interaction between quercetin and bortezomib. 
A

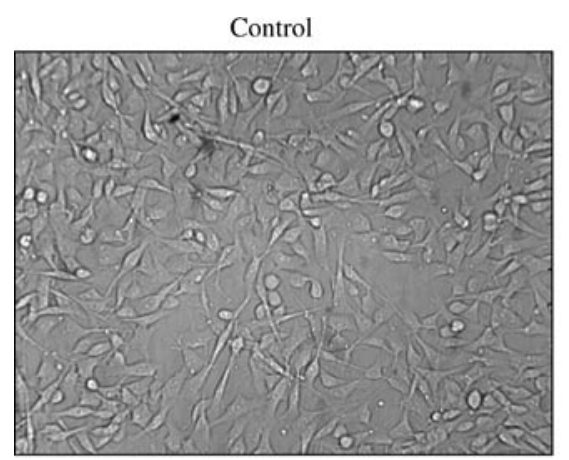

MG132

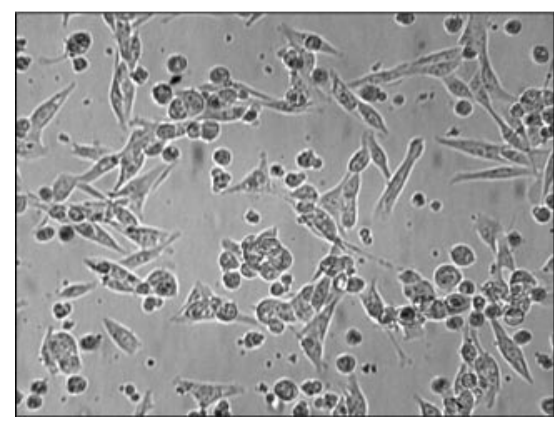

Quercetin

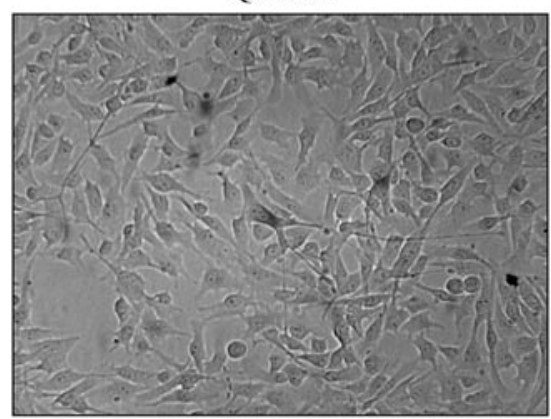

Quercetin + MG132

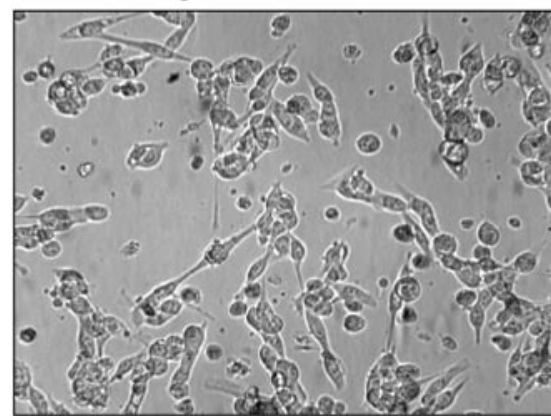

B

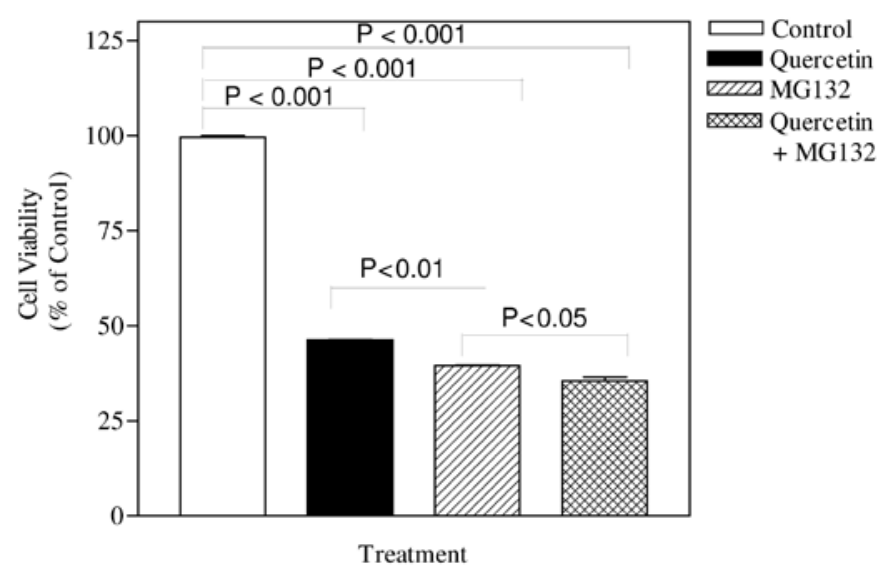

Figure 3. Determination of the combined effect of MG132 + quercetin on B16F10 cells. (A) Cell morphology was analyzed by an inverted microscope (magnification x200). (B) Cells were treated for $24 \mathrm{~h}$ with $0.5 \mu \mathrm{M}$ MG132, $20 \mu \mathrm{M}$ quercetin or quercetin $(20 \mu \mathrm{M})+\mathrm{MG} 132(0.5 \mu \mathrm{M})$. Cell viability was then determined by the MTT assay. Results are presented as the mean \pm SEM $(n=3)$.

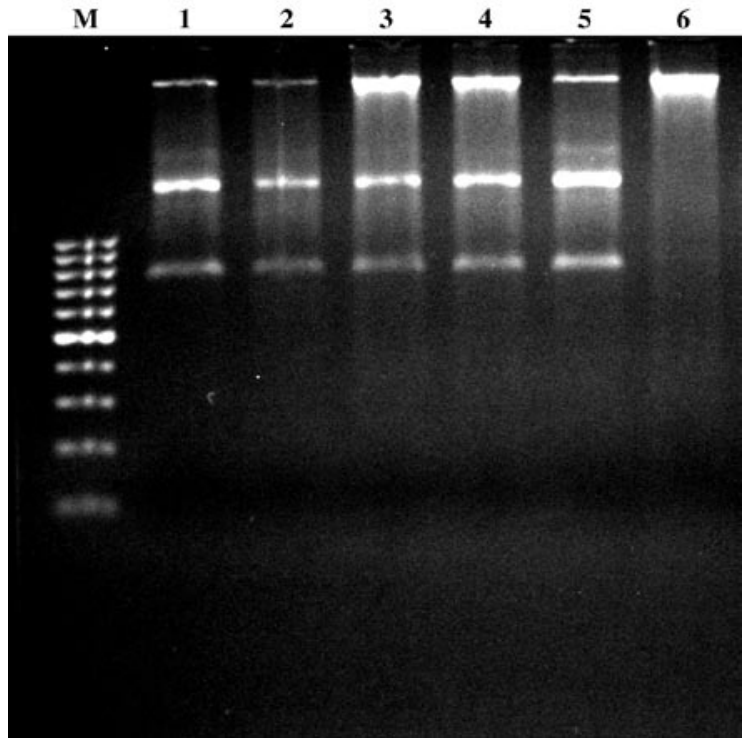

Next, we determined the combined effect of another proteasome inhibitor, MG132, with quercetin in B16F10 cells. As shown in Fig. 3A, $20 \mu \mathrm{M}$ quercetin treatment did not prevent the morphological changes induced by MG132. In addition, as shown in Fig. 3B, the MTT assay indicated that the combined effect of MG132 + quercetin differed statistically compared to quercetin or MG132 treatment alone, suggesting that i) the combination of the two inhibitors is more potent than single-agent treatment, and ii) there is no chemical reaction between MG132 and quercetin. Analysis

Figure 4. Analysis of DNA fragmentation. Cells $(100,000)$ were seeded in $35 \times 10-\mathrm{mm}$ Petri dishes and treated for $48 \mathrm{~h}$ with $20 \mu \mathrm{M}$ quercetin, $10 \mathrm{nM}$ bortezomib, $0.5 \mu \mathrm{M}$ MG132, $20 \mu \mathrm{M}$ quercetin $+10 \mathrm{nM}$ bortezomib or $20 \mu \mathrm{M}$ quercetin $+0.5 \mu \mathrm{M}$ MG132. After treatment, DNA was isolated using the Roche Apoptotic DNA Ladder kit. For each DNA sample, $0.5 \mu \mathrm{g}$ DNA was separated on a $1.5 \%$ gel. M, 100 bp marker; lane 1, control; lane 2, quercetin; lane 3, bortezomib; lane 4, MG132; lane 5, quercetin + bortezomib; lane 6, quercetin + MG132. 
A

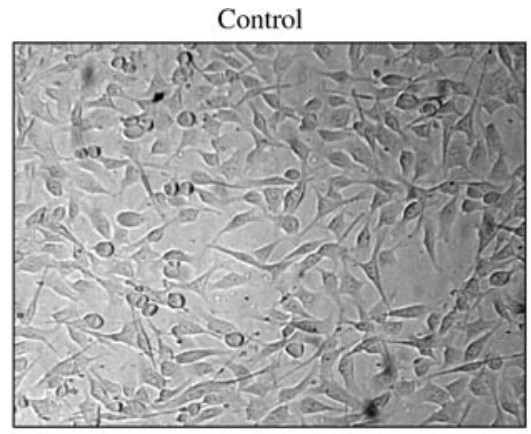

Sch-B

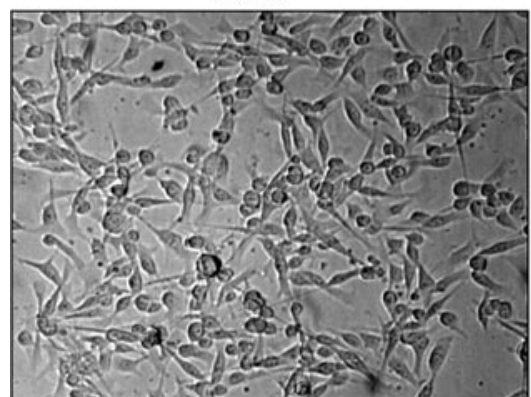

KNK-437 + Bortezomib

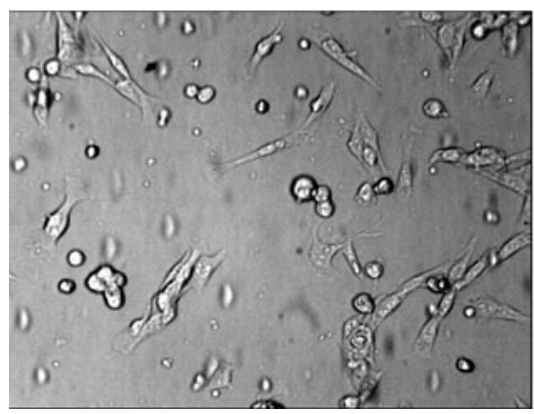

KNK-437

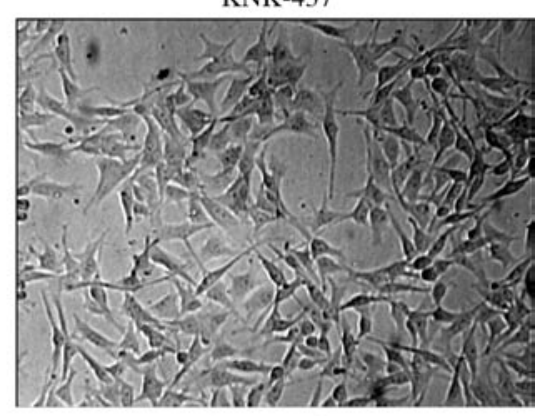

Bortezomib

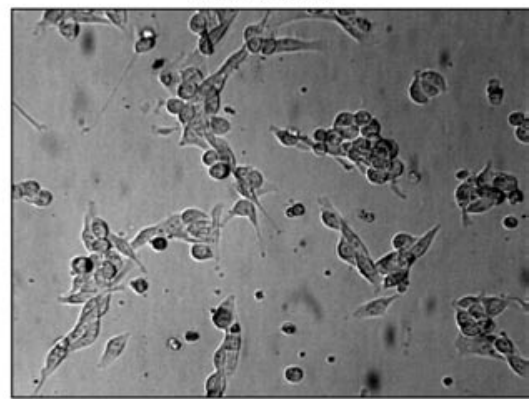

Sch-B +Bortezomib

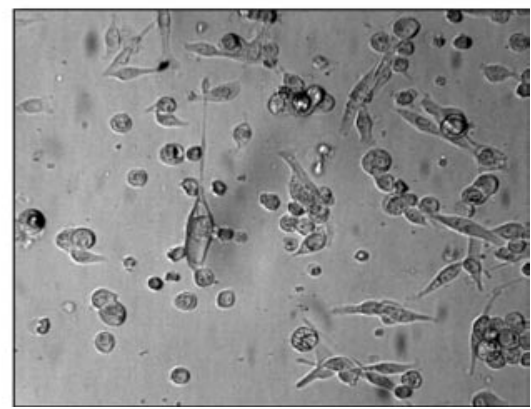

B

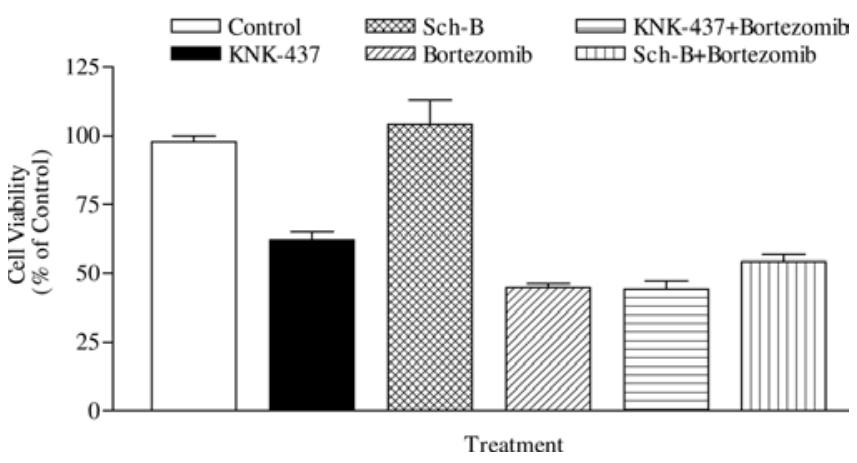

Figure 5. Effect of Hsp70 inhibitors KNK-437 and schisandrin-B (Sch-B) alone or in combination with bortezomib on B16F10 cells. Cells (50,000) were plated in sterile $35 \times 10-\mathrm{mm}$ Petri dishes and treated for $24 \mathrm{~h}$ with DMSO (control), KNK-437 (20 $\mu \mathrm{M})$, Sch-B (20 $\mu \mathrm{M})$, or bortezomib (10 nM) alone, or in combinations of KNK-437 $(20 \mu \mathrm{M})+$ bortezomib $(10 \mathrm{nM})$ or Sch-B $(20 \mu \mathrm{M})+$ bortezomib (10 nM). (A) Analysis of cell morphology (magnification x200). (B) Analysis of cell viability determined by the MTT assay. Results are presented as the mean \pm SEM ( $n=3)$.

of DNA ladder formation revealed that treatment with $10 \mathrm{nM}$ bortezomib or $0.5 \mu \mathrm{M}$ MG132 for $48 \mathrm{~h}$ induced apoptosis, while treatment with $20 \mu \mathrm{M}$ quercetin for $48 \mathrm{~h}$ was not sufficient to induce apoptosis in the B16F10 melanoma cells, a result consistent with the above cytotoxicity assay using MTT (Fig. 4). A DNA ladder assay also confirmed that quercetin inhibited the apoptosis-inducing effect of bortezomib (Fig. 4, lane 5), but did not prevent that of MG132. On the contrary, quercetin potentiated the apoptosis-inducing effect of MG132 (Fig. 4, lane 6).
Finally, we examined the effects of two other Hsp70 inhibitors, KNK-437 and schisandrin-B, in combination with bortezomib in B16F10 melanoma cells. As shown in Fig. 5A, neither KNK-437 nor schisandrin-B caused significant changes in cell morphology. In contrast to quercetin treatment, bortezomib-induced changes in cell morphology were not prevented by either KNK-437 or schisandrin-B, indicating that these two Hsp70 inhibitors did not interact with bortezomib. However, neither KNK-437 nor schisandrin-B enhanced the cytotoxic effects of bortezomib in the B16F10 cells (Fig. 5B). 


\section{Discussion}

Proteasome inhibitors cause antitumor activity in cancer cells by triggering apoptosis. Proteasome inhibitor-induced apoptosis is generally mediated by the inhibition of the processing of NF- $\mathrm{KB}$ and by the accumulation of the proapoptotic proteins Bid, Bax, p53 and p27 (28). In contrast to peptide aldehyde inhibitors, bortezomib is a highly potent and selective inhibitor of the proteasome (29). This dipeptide boronic acid analogue was the first proteasome inhibitor used in clinical trials for the treatment of a number of malignancies (including multiple myeloma, non-Hodgkin's lymphoma and non-small cell lung cancer) $(30,31)$.

Here, we report that $\mathrm{B} 16 \mathrm{~F} 10$ cells are highly sensitive to the proteasome inhibitor bortezomib. We also previously noted that B16F10 cells are rapidly proliferating cells with a doubling time of $14.2 \mathrm{~h}$ (32). In agreement with these findings, it was previously found that proteasome inhibitors preferentially induced cell death in proliferating HL60 cells, while non-cycling differentiated cells were unresponsive to proteasome inhibition (33). In addition, we found that B16F10 cells were sensitive to quercetin; however, the $\mathrm{IC}_{50}$ value for quercetin was markedly higher than that of bortezomib. In a previous study, when B16F10 cells were treated with various doses of quercetin, the MTT colorimetric assay did not reveal significant changes in cell viability, which suggested that these cells were highly resistant to quercetin (34). However, consistent with the results presented here, Kubo et al (35) found that quercetin reduced cell number in a dose-dependent manner using both the MTT assay and trypan blue exclusion test, with an $\mathrm{IC}_{50}$ value for quercetin in B16F10 cells of $20 \mu \mathrm{M}$ (35). We believe that the sensitivity of cells to quercetin is strictly dependent on the proliferation state of the cells. For example, it was found that confluent $\mathrm{B} 16 \mathrm{~F} 10$ cells were highly resistant to $100 \mu \mathrm{M}$ quercetin applied for $24 \mathrm{~h}$ (Yerlikaya and Şeker, unpublished data). As stated above, it was also previously reported that quercetin prevented borteozomib-induced apoptosis due to a chemical reaction between the two agents, while the inhibitory effect of quercetin was reversed by pre-treatment of the cells with boric acid (27). Therefore, we expected to observe an increase in the cytotoxic effects of the quercetin and bortezomib combination in the presence of boric acid.

We found that boric acid at a concentration of $1 \mathrm{mM}$ did not completely eliminate the inhibitory effect of quercetin on bortezomib-induced cytotoxicity in B16F10 melanoma cells. This result is inconsistent with a previously published report by Liu et al (27). The discrepancy may be due to the fact that we did not pre-treat the cells with boric acid, or that we did not use a high enough concentration of boric acid. However, the combination of quercetin with another proteasome inhibitor, MG132, was more cytotoxic than single-agent treatment. Analysis of DNA fragmentation also confirmed that quercetin interacted with bortezomib and inhibited its apoptosis-inducing effects, while the apoptosis-inducing effects of MG132 were potentiated by quercetin supplementation. These results suggest that a combination of quercetin with clinically effective proteasome inhibitors (except bortezomib) may be useful in the treatment of solid cancers.

We also examined the combination of the Hsp70 inhibitors KNK-437 or schisandrin-B with bortezomib. KNK-437 is a benzylidene lactam compound and a novel inhibitor of both the acquision of thermotolerance and various HSPs at the mRNA level (36). Schisandrin-B, on the other hand, is a dibenzocyclooctadiene compound that inhibits the proliferation of human hepatoma SMMC7721 cells and induces apoptosis and the down-regulation of Hsp70 expression (37). We found that KNK-437 more effectively inhibited the growth of B16F10 than schisandrin-B. However, we also found that neither KNK-437 nor schisandrin-B increased the cytotoxic effect of bortezomib in the combination treatments.

Bortezomib (Velcade ${ }^{\circledR}$ ) has recently been approved for the treatment of multiple myeloma (28). However, despite the obvious efficacy of bortezomib in many cases, a Phase II trial of bortezomib treatment in 202 patients with refractory relapsed multiple myeloma demonstrated that as many as $65 \%$ of patients did not respond to the treatment (38). In addition, resistance to bortezomib treatment in DHL-4 lymphoma cells $(39,40)$ and $4 \mathrm{~T} 1$ breast cancer cells $(32)$ was observed in in vitro experiments. Therefore, combination therapies with drugs that target different intracellular signaling pathways are warranted in order to overcome the resistance to proteasomal inhibition.

\section{Acknowledgements}

This study was funded by the Scientific and Technological Research Council of Turkey (TUBITAK) under project no. 105 S351 to A. Yerlikaya. We would like to thank Mrs. Yeliz Kiziltan (Janssen-Cilag Turkey, a division of Johson \& Johnson) and Dr Engin Ulukaya (Uludağ University, Bursa, Turkey) for providing the bortezomib used in this study. We would also like to thank Professor Xun Hu of Zhejiang University School of Medicine, Zhejiang, P.R. China, for providing the schisandrin-B.

\section{References}

1. Ding Q, Cecarini V and Keller JN: Interplay between protein synthesis and degradation in the CNS: physiological and pathological implications. Trends Neurosci 30: 31-36, 2007.

2. Goldberg AL: Protein degradation and protection against misfolded or damaged proteins. Nature 426: 895-899, 2003.

3. Hershko A and Ciechanover A: The ubiquitin system. Annu Rev Biochem 67: 425-479, 1998.

4. Hilt W and Wolf DH: Proteasomes: destruction as a programme. Trends Biochem Sci 21: 96-102, 1996.

5. Voges D, Zwickl P and Baumeister W: The 26S proteasome: a molecular machine designed for controlled proteolysis. Annu Rev Biochem 68: 1015-1068, 1999.

6. Kisselev AF, Akopian TN and Goldberg AL: Range of sizes of peptide products generated during degradation of different proteins by archaeal proteasomes. J Biol Chem 273: 1982-1989, 1998.

7. Nussbaum AK, Dick TP, Keilholz W, Schirle M, Stevanovic S, Dietz K, Heinemeyer W, Groll M, Wolf DH, Huber R, Rammensee HG and Schild H: Cleavage motifs of the yeast $20 \mathrm{~S}$ proteasome beta subunits deduced from digests of enolase 1 . Proc Natl Acad Sci USA 95: 12504-12509, 1998.

8. Glickman $\mathrm{MH}$ and Ciechanover A: The ubiquitin-proteasome proteolytic pathway: destruction for the sake of construction. Physiol Rev 82: 373-428, 2002.

9. Zwickl P, Voges D and Baumeister W: The proteasome: a macromolecular assembly designed for controlled proteolysis. Philos Trans R Soc Lond B Biol Sci 354: 1501-1511, 1999.

10. Murakami Y, Matsufuji S, Kameji T, Hayashi S, Igarashi K, Tamura T, Tanaka, $\mathrm{K}$ and Ichihara A: Ornithine decarboxylase is degraded by the $26 \mathrm{~S}$ proteasome without ubiquitination. Nature 360: 597-599, 1992. 
11. Pagano M: Cell cycle regulation by the ubiquitin pathway. FASEB J 11: 1067-1075, 1997.

12. He H, Qi XM, Grossmann J and Distelhorst CW: c-Fos degradation by the proteasome. An early, Bcl-2-regulated step in apoptosis. J Biol Chem 273: 25015-25019, 1998.

13. Yerlikaya A and Stanley BA: S-adenosylmethionine decarboxylase degradation by the $26 \mathrm{~S}$ proteasome is accelerated by substrate-mediated transamination. J Biol Chem 279: 12469-12478, 2004.

14. Pickart $\mathrm{CM}$ and Eddins MJ: Ubiquitin: structures, functions, mechanisms. Biochim Biophys Acta 1695: 55-72, 2004

15. Hershko A, Ciechanover A and Varshavsky A: Basic Medical Research Award. The ubiquitin system. Nat Med 6: 1073-1081, 2000.

16. Chau V, Tobias JW, Bachmair A, Marriott D, Ecker DJ, Gonda DK and Varshavsky A: A multiubiquitin chain is confined to specific lysine in a targeted short-lived protein. Science 243 . 1576-1583, 1989.

17. Jentsch S: The ubiquitin-conjugation system. Annu Rev Genet 26: 179-207, 1992

18. Hershko A, Ciechanover A, Heller H, Haas AL and Rose IA: Proposed role of ATP in protein breakdown: conjugation of protein with multiple chains of the polypeptide of ATP-dependent proteolysis. Proc Natl Acad Sci USA 77: 1783-1786, 1980.

19. Rock KL, Gramm C, Rothstein L, Clark K, Stein R, Dick L, Hwang D and Goldberg AL: Inhibitors of the proteasome block the degradation of most cell proteins and the generation of peptides presented on MHC class I molecules. Cell 78: 761-771, 1994.

20. Patnaik A, Chau V and Wills JW: Ubiquitin is part of the retrovirus budding machinery. Proc Natl Acad Sci USA 97: 13069-13074, 2000.

21. Yerlikaya A, Kimball SR and Stanley BA: Phosphorylation of eIF2a in response to $26 \mathrm{~S}$ proteasome inhibition is mediated by the haem-regulated inhibitor (HRI) kinase. Biochem J 412: 579-588, 2008.

22. Hershko A: Ubiquitin-mediated protein degradation. J Biol Chem 263: 15237-15240, 1988.

23. Davie JR and Murphy LC: Level of ubiquitinated histone H2B in chromatin is coupled to ongoing transcription. Biochemistry 29: 4752-4757, 1990

24. Kim D, Kim SH and Li GC: Proteasome inhibitors MG132 and lactacystin hyperphosphorylate HSF1 and induce hsp70 and hsp27 expression. Biochem Biophys Res Commun 254: 264-268, 1999.

25. Jones EL, Zhao MJ, Stevenson MA and Calderwood SK: The 70 kilodalton heat shock protein is an inhibitor of apoptosis in prostate cancer. Int J Hyperthermia 20: 835-849, 2004.

26. Samali A and Cotter TG: Heat shock proteins increase resistance to apoptosis. Exp Cell Res 223: 163-170, 1996.

27. Liu FT, Agrawal SG, Movasaghi Z, Wyatt PB, Rehman IU, Gribben JG, Newland AC and Jia L: Dietary flavonoids inhibit the anticancer effects of the proteasome inhibitor bortezomib. Blood 112: 3835-3846, 2008.
28. Adams J: The development of proteasome inhibitors as anticancer drugs. Cancer Cell 5: 417-421, 2004.

29. Burger AM and Seth AK: The ubiquitin-mediated protein degradation pathway in cancer: therapeutic implications. Eur J Cancer 40: 2217-2229, 2004.

30. Chauhan D, Hideshima T, Mitsiades C, Richardson P and Anderson KC: Proteasome inhibitor therapy in multiple myeloma. Mol Cancer Ther 4: 686-692, 2005.

31. Voortman J, Checinska A and Giaccone G: The proteasomal and apoptotic phenotype determine bortezomib sensitivity of non-small cell lung cancer cells. Mol Cancer 6: 73, 2007.

32. Yerlikaya A and Erin N: Differential sensitivity of breast cancer and melanoma cells to proteasome inhibitor Velcade. Int J Mol Med 22: 817-823, 2008.

33. Drexler HC: Activation of the cell death program by inhibition of proteasome function. Proc Natl Acad Sci USA 94: 855-860, 1997.

34. Rodriguez J, Yanez J, Vicente V, Alcaraz M, Benavente-Garcia O, Castillo J, Lorente J and Lozano JA: Effects of several flavonoids on the growth of B16F10 and SK-MEL-1 melanoma cell lines: relationship between structure and activity. Melanoma Res 12: 99-107, 2002.

35. Kubo I, Nitoda $T$ and Nihei K: Effects of quercetin on mushroom tyrosinase and B16-F10 melanoma cells. Molecules 12: 1045-1056, 2007

36. Yokota S, Kitahara $\mathrm{M}$ and Nagata K: Benzylidene lactam compound, KNK437, a novel inhibitor of acquisition of thermotolerance and heat shock protein induction in human colon carcinoma cells. Cancer Res 60: 2942-2948, 2000.

37. Wu YF, Cao MF, Gao YP, Chen F, Wang T, Zumbika EP and Qian KX: Down-modulation of heat shock protein 70 and up-modulation of caspase-3 during schisandrin B-induced apoptosis in human hepatoma SMMC-7721 cells. World J Gastroenterol 10: 2944-2948, 2004.

38. Richardson PG, Barlogie B, Berenson J, et al: A phase 2 study of bortezomib in relapsed, refractory myeloma. N Engl J Med 348: 2609-2617, 2003

39. Hideshima T, Chauhan D, Ishitsuka $K$, Yasui H, Raje $N$, Kumar S, Podar K, Mitsiades C, Hideshima H, Bonham L, Munshi NC, Richardson PG, Singer JW and Anderson KC: Molecular characterization of PS-341 (bortezomib) resistance: implications for overcoming resistance using lysophosphatidic acid acyltransferase (LPAAT)-beta inhibitors. Oncogene 24: 3121-3129, 2005

40. Chauhan D, Li G, Shringarpure R, Podar K, Ohtake Y, Hideshima T and Anderson KC: Blockade of Hsp27 overcomes bortezomib/proteasome inhibitor PS-341 resistance in lymphoma cells. Cancer Res 63: 6174-6177, 2003. 